A word as to verse I $_{5}$. There cannot be much doubt that it is an interpolation. Attempts have been made, it is true, to demonstrate its relevancy, and to shew its connexion with the context. Now Rendel Harris thinks that he has found, in his suggestion regarding $\dot{\epsilon} \xi \eta \dot{\eta} \sigma a r o$,

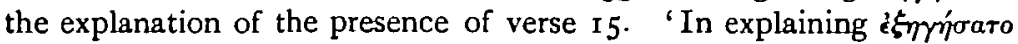

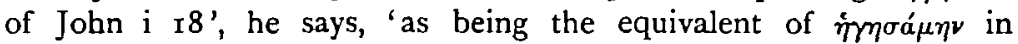
Sirach xxiv 6, we have found the reason for the little inserted testimony of John the Baptist in John $i_{15}$, which is also occupied with the doctrine of the priority and primacy of Jesus.' ${ }^{1}$ Whether this means that the testimony was inserted by the Evangelist or by some one else, one naturally asks why the words were not placed after verse $r 8$ instead of in the utterly unsuitable position which they occupy in the traditional text; and if we are right in rejecting the new interpretation of $\dot{\epsilon} \xi \eta \eta^{\prime} \sigma a \tau o$, then of course Dr Harris's suggestion regarding verse 15 goes with it. Dr Moffatt is surely justified in treating verse $I_{5}$, not as part of the original text, but as a marginal gloss based on verse 30 which has succeeded in wedging itself into its present position." It would be interesting to know the history of this interpolation. It may not be profitable to surmise overmuch, but I wonder whether its origin is to be found in words placed in the margin of some early manuscript

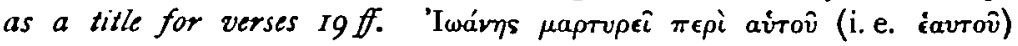
exactly describes verses 19-28. Airtôv would easily be taken as aurôิ, and the reference transferred from the Baptist to Christ. The rest of verse 15 , quoting verse 30 , may have originated as a marginal title of verses 29-34, which deal with John's announcement of Jesus. These suggestions are admittedly tentative, but the utter want of congruence between verse 15 and its traditional context seems to preclude all hypotheses save that of accidental misplacement.

J. Hugh Michael.

\title{
THE BRINGING FORTH OF THE SOUL IN IRISH LITERATURE.
}

IN various apocryphal writings both of the Old and New Testament a description is given of the difficulty attached to the act of bringing forth the soul of a righteous man, no doubt with the object of enhancing his dignity and of accentuating the importance of his life on earth. Thus the patriarch Abraham refuses to yield up his soul until Death deceives him, and gives bim his right hand, to which Abraham's soul

1 Origin, Ec. p. 40.

$I L N T$ p. $55^{2}$. 
cleaves. Similarly Adam is unwilling to die, because he alleges that if he is taken away there will be no one to till the ground. In a Coptic account of the death of Joseph, the husband of the Virgin, it is said that when dying he beheld Death and Amente approaching, with their dread attendants. At this 'the soul of Joseph wished to go forth with great disquietude, and was seeking a place to hide in, and found not a place'. Then Michael and Gabriel and the heavenly choir approach, and Joseph 'keeps labouring as one about to give birth, affliction pursuing after him as a violent wind'. Finally Jesus admits Death (who has hidden himself behind the door), who brings forth the soul, which Michael and Gabriel wrap in a silken napkin. ${ }^{1}$

In other writings the difficulty of bringing forth the soul through certain specified members of the body is described. Thus in the Apocalypse of Esdras the prophet says, 'Whence can you bring forth my soul?' And the angels reply, 'We can bring it forth through the mouth'. And the prophet answered, 'Mouth to mouth have I spoken with God, and it comes not thence'. The angels said, 'Let us bring it out through the nostrils'. And the prophet said, 'My nostrils have smelled the sweet savour of the glory of God'. The angels then suggest the eyes, the crown of the head, and the points of the nails, but the prophet refuses to allow it to come forth through any of these. Somewhat similar incidents occur in a recension of the De Morte Mosis and in the Apocalypse of Sedrach. Dr James thinks that the above were derived from some common source, which was probably the Assumption of Moses. He also states that a similar episode occurs in Mohammedan mythology, where the Angel of Death cannot bring the soul out by various parts of the body, because they have been sanctified in various ways. ${ }^{2}$

So much has been said by way of preface.' There exists in Irish literature a passage which although descriptive of the death of a sinner rather than of a righteous man, yet so closely resembles the last-quoted pieces that one is tempted to believe that it has been influenced by one or other of them, directly or indirectly. It exists in a version of the Dispute between the Soul and the Body. Of this well-known piece two versions are found in Irish, which differ widely from each other. The first of these has been published by G. Dottin in the Revue Celtique xxiii, and is not of much importance, as it is almost identical with the metrical Latin version published by Wright in his Poems attributed to Walter Mapes. The other, which contains the passage alluded to, has been published by Atkinson in his Passions and

1 James Testament of Abraham p. 2 ; Malan Book of Adam and Eve p. 226 ; Robinson Coptic Apocryphal Gospels pp. I39-141, I 55-1 59 .

2 Tischendorf Apocal. Apacr. p. $3^{1}$; James Test. $A b$. pp. 64-68.

VOL. XXII. 
Homilies from the Leabhar Breac (Todd Lect. Series, p. 507). As it is very interesting in form a brief analysis will not be out of place. St Augustine is credited with saying that two hosts come to meet the soul at its departure, angels the good, devils the bad. The version is almost entirely taken up with the experiences of the latter soul. The demons abuse and revile it while it is still in the body. They then tell it that it is time for it to leave its abode. The soul in its despair tries to escape by the mouth, but finds its way blocked by Death, which forbids its exit. Similarly it goes to the nose, eyes, and ears, but with no better success, for at each of these Death awaits it : finally it ascends through the crown of the head. The devils then mock and beat it. It repents of its sins, and tries to fly heavenward; the devils in mockery allow it to go a little way, and then rush after it and catch it. The soul then turns back and abuses the body, which answers it. Each speaks only once. Then the body bids the soul depart to Hell. A pleasant host of angels escorts the good soul to Heaven. With respect to this version $H$. Gaidoz says (Reoue Celtique x p. 463): 'The originality of the Irish text is that it belongs at one and the same time to the literature of visions and to that of the Disputes, so that one sees clearly how the dialogue of the soul and the body, before becoming a subject in itself, was only an incident in the general story of a vision.'

This motive reappears, somewhat amplified, in a late and rather distorted Irish version of the Vision of St Paul. According to the unknown author St Paul is permitted to witness the dying of a sinner. He finds that Death has seized all the sick man's body, except the lower chamber of the heart, where the soul is endeavouring to conceal itself-an incident which reminds us of the account of Joseph's death quoted above. Death then commences to plough and bore at the heart, and the soul tries to escape by the mouth, but finds there a host of black loathsome devils awaiting it. It then goes to the nose, eyes, and ears, with the same result. Finally it goes out through the crown of the head. ${ }^{1}$

We must now consider an account of the death of the sinner and of the righteous which is found in Latin (and said. to be a translation from the Greek) in the De Vitis Patrum. A version also exists in Coptic. A certain holy man desired to see how the souls of the sinner and of the righteous are taken away. As be sat in his cell a wolf came to him, and catching bold of his clothes, drew him out of the house. He came to a monastery outside the city, where lay at the point of death a certain man who was reputed to be a renowned solitary. Then his hour came the brother saw an evil spirit (tartaricus infermi) with

1 Duuglas Hyde Legends of Saints and Sinners pp. 97-99. 
a fiery trident descending upon the solitary, and heard a voice saying: 'As this soul has not allowed me to rest, even for one hour, so do you pluck it forth without pity.' Then the demon plunged the fiery trident into the heart of the solitary, and twisting it about for some time, drew out the soul. Then the monk witnessed th 2 death of a righteous pilgrim. Michael and Gabriel are sent to fetch the soul, but it will not come forth. Finally Michael makes complaini to God, who says that He will send David and the heavenly choir, and when they come singing the soul goes out ${ }^{1}$

There is an exactly similar narrative in Irish literature, entitled The The Deaths. The editor has not succeeded in dating it, unfortunately, but contents himself with saying that the language gives evidence of considerable age. A certain monk was forty years in the desert. As he was a-fasting for God the death of the sinner and of the righteous was revealed to him. He goes into a city, being guided by a beast which took the brooch out of his cloak, and which he was directed to follow. . The ruler of the city is at the point of death. Satan entered the house, having a fiery three-pronged fork in his hand. He leaped upon the breast of the sick man, and thrice turned himself over to the left upon him. Then a voice is heard coming from the dying man. 'Since thou hast not done my will for the space of even one hour, O unhappy soul, therefore I shall give you up to everlasting pain.' As often as the soul came to the man's mouth Satan dealt it a blow with his fork, so that the soul turned back to the body again. But Satan once plunged the three-pronged fork under the left breast of the man, and dragged the soul forth from the body to the floor. It was as black as a raven. It then gave voice to three utterances. 'Great is the darkness.' Satan answered, 'Greater still remains for you'. Then Satan took the soul in his hand, and went through the middle of the house, so that the monk beheld it. Then it said, 'Steep is the road'. Satan replied, 'Steeper still remains' for you'. Its last utterance was, 'Great are the straits'. Satan replied, 'Greater still remains for you'. The soul then went round the body by the left, and cursed it. Then it went to the door of the house, and two bands of demons met it and escorted it to Hell, one before and one behind. Then the monk went to the house of a good man, and saw Michael and Gabriel : the former went up to the pillow of the dying man [gap in text. No doubt the original described the soul's reluctance to come forth]. Then was heard the singing of the heavenly host with David as it approached. The soul sprang upon the breast of the man, and it was resplendent as the sun. It, too, spoke thrice. 'Great is that light.' The angel replied, 'Greater thou wilt have'. 'The ways are smooth.' 'Smoother

1 Migne P. L. Ixxiii p. Ior I. For Coptic see ref. in Robinson, p. 23.3. 
will they be for thee.' 'The ways are broad.' 'Broader will they be for thee.' 1

The above contains some peculiarly Celtic touches introduced by the unknown redactor, such as the allusion to the brooch in the cloak, and possibly the 'three utterances'. The description of Satan turning himself over to the left, and of the soul going round the body by the left, recalls the prevalent belief in Ireland that it is extremely unlucky to go round anything contra-sunwise. The opposite way is the propitious one, e.g. at holy wells pilgrims make their 'rounds' following the course of the sun, or in other words, with their right side kept continuously towards the well. But apart from these touches, which are only to be expected, it is clear that the Irish writer knew and made use of the passage in the De Vitis Patrum, which comes pretty near saying that we have here a direct. connexion between Irish and Eastern literature.

The Two Deaths and the L. B. version of the Dispute have certain points in common. In both a mention is made of the two hosts; and the soul is prevented from escaping through an organ of the body. Again, whereas in the other version of the Dispute the soul and body speak to each other several times, in the L. B. version they only address each other once, which brevity of dialogue is represented in The Two Deaths by the solitary remark addressed by the body to the soul. There is thus some literary connexion between the two documents, and it would be interesting to know which of them is the older.

A similar story is found outside Ireland. In the life of St Lietbert, written by Rodulph, abbot of St Trudo (who died in $1 \mathbf{r}^{8} 8$ ), it is related that a certain count, named Fulcher, who was lying dangerously ill, saw by his bedside two devils carrying a flaming iron trident, which they termed the 'sting of death'. They told him that they had brought it in order that they might plunge it into his heart, and so cast out his soul. Whereupon he called upon the Virgin and St Andrew, and was saved by them. One is reminded of Bede's story of the wicked soldier, whom two evil spirits struck with forks, one on the head, and the other on the foot. These strokes were gradually penetrating through his bowels to the inward parts of his body, and he knew that when they met he would die, and be dragged off to Hell."

\section{St J. D. Seymour.}

1 Erin v p. I21 ff. The two sets of 'three utterances', and some words just before the break in the text, are in Latin.

' Migne $P$. L. cxlvi p. I 469 ; Bede $H . E$. v chap. 13 . 